\title{
ODPOWIEDZIALNOŚĆ UCZELNI ZA KSZTALTOWANIE POSTAW OBYWATELSKICH STUDENTÓW
}

\section{WSTĘP}

Poruszane w artykule zagadnienie może zostać uznane przez niektórych za banalne, gdyż przy przyjęciu pewnej jego interpretacji na zawarte pytanie problemowe nasuwa się, ich zdaniem, oczywista odpowiedź. Uczelnia bowiem oprócz tego, że przekazuje wiedzę merytoryczną (fachowa), to w trakcie kształcenia uczy krytycznego stosunku do świata. Zatem chociażby w tym aspekcie nie tylko przygotowuje do przyszłego zawodu, lecz także uwzględnia fakt, iż jej absolwenci, którzy będą pełnili różne funkcje w życiu społecznym, politycznym itp., powinni (jako skutek uboczny edukacji zawodowej) uzyskać pewien kapitał intelektualny (umiejętność krytycznego myślenia). Przy takiej „banalnej” interpretacji dyskusję nad tym zagadnieniem można uznać za skończona.

Jednakże nawet jeśli zgodzić się z powyższą sugestia, że na tak sformułowane pytanie nasuwa się oczywista odpowiedź, to warto jednak rozważyć założenia, które leżą u podstaw takiej interpretacji, a te mogą się okazać zdecydowanie bardziej złożone. Próba przedstawienia takiej bardziej złożonej interpretacji problemu będzie celem niniejszego tekstu.

Jeśli bowiem tytuł mojego artykułu potraktować jako osnowę pytania rozstrzygnięcia, która zawiera założenie pytania, to w przypadku tak sformułowanego problemu (którego językowym wyrazem jest powyższe pytanie), należałoby rozważyć kilka elementów, które są istotne dla zrozumienia tego założenia. Ze względu na ograniczoną objętość tekstu nie jestem w stanie omówić wszystkich kwestii, które w tym kontekście się nasuwają. Ograniczam się jedynie do zwrócenia uwagi na pewne ogólne ramy pojęciowe, w obrębie których można rozważać w bardziej złożonej interpretacji problem przypisania uczelni odpowiedzialności za kształtowanie postaw obywatelskich studenta.

Nie dążę do tego, aby udzielić jakiejś ostatecznej odpowiedzi, lecz wskazuję na wchodzące $\mathrm{w}$ grę rozwiązania, które są uwarunkowane przyjęciem takich lub innych założeń (rozstrzygnięć) o charakterze np. ontologicznym, epistemologiczno-metodologicznym, czy też aksjologicznych. Wydobycie tego typu założeń, zazwyczaj przyjmowanych tacite, uważam za podstawowy, pierwszy krok w badaniu interesującego nas problemu, gdyż pokazuje zależności między pewnymi (nierzadko intuicyjnie) przyjmowanymi przekonaniami na temat sposobu istnienia, struktury i dynamiki czy też zbioru uznawanych war- 
tości, które decydują o formie wchodzaçcych w grę odpowiedzi. Nie oznacza to, że proponuję jakiś relatywizm pojęciowy czy też wycofany sceptycyzm; wręcz przeciwnie, staram się wskazać, jakie „koszty” oraz „zyski” niesie z sobą każde $\mathrm{z}$ wchodzących w grę stanowisk, które można rozpatrywać jako odpowiedź na to pytanie.

Powyższy cel będę realizował w następujących krokach. Omówię: 1) problem ontologiczny, czyli kto jest nośnikiem domniemanej odpowiedzialności (podmiot odpowiedzialności), 2) problem epistemologiczny, czyli kwestię wyróżnionej pozycji uczonych w stosunku do pozostałych członków społeczności, 3) problem aksjologiczny, czyli kwestię zróżnicowania stylów życia i wyznawanych wartości we współczesnych społeczeństwach opartych na wiedzy, 4) zagadnienie inflacji informacji oraz rozmytych kryteriów demarkacji określających rzetelne poznania i poznanie pozorne, czyli kwestię fenomenu postprawdy, jako zjawiska zagrażającego racjonalnym postawom obywateli, 5) przemiany w obszarze wzorców uprawiania nauki: od «republiki uczonych» do "dobrze uporządkowanej nauki», 6) pozycję ekspertów, w kontekście kategorii reprezentacji różnych opcji aksjologicznych przy okazji prezentacji wiedzy dla obywateli w ramach instytucji społeczno-politycznych społeczeństwa opartego na wiedzy, 7) sformułuję ostateczne konkluzje dotyczace zasadności wysuniętej hipotezy, że uczelnia jest odpowiedzialna za kształtowanie postaw obywatelskich studentów.

\section{PROBLEM ONTOLOGICZNY, CZYLI KTO JEST PODMIOTEM ODPOWIEDZIALNOŚCI}

Jako przykład zagadnienia, w ramach którego dyskutuje się kwestię, komu można przypisać status podmiotu odpowiedzialności, a który można określić mianem problemu on tologicznego, można przywołać dyskusje we współczesnej ontologii społecznej. Dyskusje te dotyczą indywidualistycznego/antyindywidualistycznego ujęcia grupy społecznej (w tym i instytucji społecznych, takich jak uniwersytety i inne jednostki wyższej edukacji). W drugim ujęciu można im przypisać charakterystykę sui generis, która byłaby nieredukowalna do poziomu elementów składowych. Innymi słowy, pytanie dotyczy tego, kto jest podmiotem owej odpowiedzialności (problem poziomów: jednostkowy/mezo/zbiorowy). Czy możemy rozumieć uniwersytet jako podmiot zbiorowy (corporate agent), któremu można przypisać odpowiedzialność w sensie instytucjonalnym, czy też podmiotem odpowiedzialności mogą być jedynie (w mocnym sensie) poszczególni pracownicy tego uniwersytetu, a inne użycia terminu „odpowiedzialność” maja jedynie sens pochodny lub metaforyczny?

Kwestii tej nie rozwijam, a jedynie sygnalizuję wchodzące $\mathrm{w}$ grę rozwiązania, z jakimi możemy się spotkać w dyskusjach we współczesnej ontologii społecznej. Ze względu na zróżnicowanie więzi społecznej konstytuującej grupę możemy mieć: 
a) podejścia indywidualistyczne, prezentowane przez Seumasa Millera, Daniela Little’a, Stephena P. Turnera tzn. własności, które miałby charakteryzować grupę (instytucje) i które niezależnie od ich emergentnego charakteru w ostatecznym ujęciu są własnościami określającymi indywidua ${ }^{1}$;

b) podejścia antyredukcjonistyczne (kolektywistyczne czy - jak niektórzy wola je określać - antysyngularystyczne) reprezentowane przez takich autorów, jak Margaret Gilbert (plural subject), Philip Pettit (corporate person), John R. Searle (we-inetentionality), Raimo Tuomela (we-mode), w którym grupie społecznej (instytucji) przypisuje się nieredukowalne do indywiduów własności (charakterystyki), a co najmniej odmienny od indywiduów modus operandi $i^{2}$

c) podejścia pośrednie, które odwołuje się do pojęcia wzajemnego podzielania pewnych nastawień i przekonań (sharedness) Michaela Bratmana ${ }^{3}$.

W zależności od przyjętego rozwiązania odpowiedzialność mogłaby być przypisana uczelni rozumianej jako społeczny podmiot instytucjonalny (w sensie nazw zbiorowych o heterogenicznych desygnatach w rozumieniu kolektywnym, a nie dystrybutywnym, by przywołać sformułowanie wybitnego poznańskiego logika i teoretyka prawa Zygmunta Ziembińskiego) ${ }^{4}$. Tak rozumiana instytucja funkcjonuje wedle określonego nastawienia zbiorowych intencjonalności czy też mocnego modusu - my oraz przyjmuje racjonalność co do celów takiego podmiotu społecznego. W ujęciach słabszych odpowiedzialność byłaby własnością podzielaną przez współpracujące z sobą podmioty, które w działaniu kooperacyjnym poczuwają się do jej re-

${ }^{1}$ S. Miller, Social Action: A Teleological Account, CUP, Cambridge 2000; idem, Against collective agency, w: G. Meggle (ed.), Social Facts \& Collective Intentionality, Bd. 1: Zu Philosophische Forschung / Philosophical Research, J. Brandl et al. (Hrsg.), European Science Library, 2002, s. 273-298; D. Little, New Directions in the Philosophy of Social Science, Rowman and Littlefield, London-New York 2016; S. Turner, What do we mean by 'we??, „ProtoSociology” 18(2003).

${ }^{2}$ M. Gilbert, On Social Facts, PUP, Princeton 1989; idem, Living Together: Rationality, Sociality and Obligation, Rowmam \& Littlefield Publishers, Landham 1996; idem, In search of sociality, philosophical explorations, „An International Journal for the Philosophy of Mind and Action” 1(3), 1998, s. 233-241; idem, Sociality and Responsibility: New Essays in Plural Subject Theory, Rowmam \& Littlefield Publishers, Landham 1999; idem, A Theory of Politcal Obligation: Membership, Commitment and the Bonds of Society, OUP, Oxford 2004; C. List, P. Pettit, Group Agency: The Possibility, Design and Status of Corporate Agents, OUP, Oxford 2011; J.R. Searle, The Construction of Social Reality, The Free Press, New York 1995; idem, Social ontology and the philosophy of society, „Analyse und Kritik” 20, 1998, s. 143-158; idem, Rationality in Action, MIT Press, Cambridge, MA, 2001; R. Tuomela, In Search for the Common Mind: A Critical Notice of Philip Pettit's 'The Common Mind', „International Journal of Philosophical Studies” 2, 1994, s. 306-321; idem, A Theory of Social Action, D. Reidel, Dordrecht 1994; idem, The Importance of Us, SUP, Stanford 1995; idem, Cooperation: A Philosophical Study, Kluwer Academic Press, Dordrecht 2000; idem, The Philosophy of Social Practices: A Collective Acceptance View, CUP, Cambridge 2002; idem, The Philosophy of Sociality: The Shared Point of View, OUP, Oxford 2007.

${ }^{3}$ M.E. Bratman, Intention, Plans, and Practical Reason, HUP, Cambridge, MA, and London, England 1987; idem, Shared cooperative activity, „The Philosophical Review” 101(2), 1992, s. 327-340; idem, Shared intention, „Ethics” 104, 1993, s. 97-113; idem, Faces of Intention, Selected Essays on Intention and Agency, CUP, Cambridge 1999; idem, Structures of Agency: Essays, OUP, Oxford 2007.

${ }^{4}$ Z. Ziembiński, Logika praktyczna, PWN, Warszawa (wiele wydań). 
alizacji. W najsłabszym (ontologicznie) rozwiązaniu odpowiedzialność wiązałaby się z pewnym jednostkowym reprezentowaniem określonego zbioru wartości, które jednostki skłonne są uznawać za ważne i zobowiązują się je respektować. Zagadnienie, które z rozwiazań byłoby najbardziej stosownym w interesującej nas kwestii odpowiedzialności instytucjonalnej, wymagałoby bardziej szczegółowych prezentacji i analiz, niż pozwala na to objętość tego tekstu.

\section{PROBLEM EPISTEMOLOGICZNY}

Inny problem, który w tym kontekście się nasuwa, dotyczy społecznych funkcji pełnionych przez ludzi nauki (uczonych), można go określić mianem problemu epistemologicznego. Problem ten wiąże się z pełnieniem przez ludzi świata nauki różnych ról społecznych (na co przed laty zwrócił uwage Florian Znaniecki ${ }^{5}$ ), czyli faktu wyjścia przez uczonych poza czysta naukę (np. funkcje doradcze), a który obecnie określa się mianem problemu ekspertów i dyskutuje na temat ich statusu w społeczeństwie demokratycznym (liberalnej demokracji). Jednym z istotnych zagadnien jest kwestia asymetrii poznawczej na linii ekspert-obywatel (wiedza lokalna), a także problem polityzacji nauki, zwłaszcza w kontekście podejmowania decyzji, których konsekwencje mają dotyczyć wszystkich obywateli (czy też wspólnot ponadnarodowych) $)^{6}$ :

1) eksperci z jednej strony dostarczają wiedzy tym, którzy jej nie posiadaja, a zarazem jej potrzebuja do oceny sytuacji, w której się znajduja, jak również do podjęcia właściwych środków zaradczych (czy też przewidywań dalszej sekwencji zdarzeń), jednym słowem chodzi o zleceniodawców zadań eksperckich. Jednak problem pojawia się w sytuacji, gdy opinie ekspertów na dany temat sa zupełnie rozbieżne, jak również gdy zleceniodawcy usług eksperckich tak dobierają ekspertów, aby uzasadnić planowane działania (bądź też ich zakończenie). Tego typu sytuacje prowadzą do zjawiska, które określić można terminem polityzacji nauki (Mark Brown');

2) z drugiej strony pojawia się problem wiedzy ekspertów w stosunku do tych, do których podejmowane działania będą się stosowały. W tym drugim kontekście pojawia się bardzo istotne pytanie, które można trafnie sformułować, używając języka Jürgena Habermasa: czy wiedza ekspertów kolonizuje

${ }^{5}$ F. Znaniecki, Spoteczne role uczonych, PWN, Warszawa 1984; idem, The Social Role of the Man of Knowledge, Transaction Books, New Brunshwick 1986. Zob. także R.P. Wierzchosławski, Floriana Znanieckiego Społeczne role uczonych w kontekście wspótczesnego naukoznawstwa $i$ socjologii wiedzy naukowej, „Humaniora. Czasopismo Internetowe” 2016, nr 1(13), s. 111-130.

${ }^{6}$ S.P. Turner, Liberal Democracy 3.0: Civil Society in the Age of Experts, Sage, London 2003; idem, The Politics of Expertise, Routledge, London 2014; R. Grundmann, R. Stehr, Experts: The Knowledge and Power of Expertise, Routledge, London 2012.

${ }^{7}$ M. Brown, Science in Democracy: Expertise, Institution and Representation, MIT Press, Cambridge, MA, 2009. 
wiedzę lokalną? Zwłaszcza że nie zawsze te rady są trafne, zasadne i nie ma gwarancji, że nie prowadzą do błędów (problem społeczeństwa ryzyka Urlich $\operatorname{Beck}^{8}$;

3) inna jeszcze, pokrewną kwestią jest konieczność współdziałania ekspertów i laików w celu skutecznego zastosowania wiedzy eksperckiej, która, aby przyniosła efekty, (a) musi zyskać akceptację np. lokalnych mieszkańców, (b) musi zostać w pewnych szczegółach dostosowana do lokalnych warunków (np. rolnictwo), co zakłada, że stosujący wiedzę ekspercką musi uznać fachowość lokalnych mieszkańców dotyczącą pewnych specyficznych uwarunkowań ${ }^{9}$.

$\mathrm{W}$ kontekście problemów związanych $\mathrm{z}$ różnymi aspektami stosowania wiedzy eksperckiej w interesującym nas kontekście odpowiedzialności uczelni za postawy obywatelskie studentów, jest wskazanie na konieczność uwrażliwiania studentów (w procesie dydaktycznym) na określone zjawiska oraz wyrabianie u nich krytycznego podejścia do wypowiedzi tych, którzy powołują się na autorytet ekspertów, a także skłaniania ich do szukania racji w sytuacji rozbieżnych i wykluczających opinii oraz wskazywanie na polityczne uwikłania ekspertów uzasadniających działania w różnych obszarach społecznych, kulturowych, politycznych itp. Do kwestii tej powrócę w dalszej części tekstu.

\section{PROBLEM AKSJOLOGICZNY}

Kolejny problem, który pojawia się w kontekście, to kwestia określenia przedmiotu odpowiedzialności uczelni, na który miałaby zwracać uwagę studentom. Kwestię tę można określić mianem proble mu a ksjologicznego, ponieważ dotyczy ona możliwości zdefiniowania odpowiedzialności obywatelskiej w czasach politeizmu aksjologicznego, by posłużyć się terminem Maxa Webera z jego Nauka jako zawód i powołanie na określenie zróżnicowania i pluralizmu w sferze wartości, które nastapiło w wyniku procesów modernizacyjnych ${ }^{10}$. Kwestia ta dotyczy zagadnienia określenia wartości, za które uniwersytet miałby być odpowiedzialny zarówno w sferze prywatnej, jak

\footnotetext{
${ }^{8}$ U. Beck, Spoteczeństwo ryzyka. W drodze do innej nowoczesności, tłum. S. Cieśla, Scholar, Warszawa 2002; idem, Wtadza i przeciwwładza w epoce globalizacji. Nowa ekonomia polityki światowej, tłum. J. Łoziński, Scholar, Warszawa 2002.

${ }^{9}$ F. Fischer, Citizens, Experts, and the Environment: The Politics of Local Knowledge, Duke University Press, Durham, NC, - London 2000; idem, Democracy and Expertise: Reorienting Policy Inquiry, OUP, Oxford 2009.

${ }_{10}$ M. Weber, Polityka jako zawód i powotanie, tłum. A. Kopacki, P. Dybel, przedmowa, wstęp, oprac. Z. Kranodębski, Znak, Kraków 1989, s. 55-110; Na temat politeizmu aksjologicznego w kontekście obywatelstwa R. Wierzchosławski, Politeizm aksjologiczny, władza ekspertów, a wolność obywateli. Kilka uwag o meandrach wiedzy, władzy i republice, w: A. Gawkowska, P. Gliński, A. Kościański (red.), Teorie wspólnotowe a praktyka społeczna: Obywatelskość, polityka, lokalność, IFiS PAN, Warszawa 2005, s. 82-109; a w kontekście powinności nauczyciela akademickiego warto uwzględnić analizy R. Kleszcza, Nauczyciel akademicki: neutralność czy aksjologiczne zaangażowanie?, „Etyka” 44, 2011, s. 79-96, w których autor porównuje stanowisko Webera z etycznymi i aksjologicznymi poglądami Lazari-Pawłowskiej.
} 
i publicznej, a także określenia roli, jaką miałyby pełnić nauki społeczne w odniesieniu do aktywności obywatelskiej ${ }^{11}$. W tym kontekście należy uwzględnić fakt zróżnicowania stylów życia, wielości orientacji aksjologicznych, które sa przyjmowane zwłaszcza w coraz bardziej wielokulturowych społeczeństwach, przy jednoczesnym przyjęciu założenia, że wszystkie wchodzące w grę opcje (możliwe wybory), przed którymi stają jednostki, mają taką samą wartość (teza o braku obiektywnej hierarchii wartości), a instytucje państwa demokracji liberalnej z definicji nie preferuja żadnej z „odmiennych rozległych doktryn moralnych, metafizycznych czy religijnych”, by posłużyć się terminologia Johna Rawlsa ${ }^{12}$.

Tego typu obraz relacji między różnymi opcjami aksjologicznymi jest bardziej modelem filozoficznym niż faktycznie realizowana praktyka polityczna, nawet w krajach, które bardzo mocno podkreślają swój neutralny stosunek do szeroko rozumianych kwestii aksjologicznych, jak Francja, by przywołać zakaz noszenia ostentacyjnych symboli religijnych (a w jakimś sensie i etnicznych) we francuskich szkołach publicznych, czy szerzej - kwestię obecności religii w przestrzeni publicznej świeckiego państwa demokracji liberalnej ${ }^{13}$.

W tym kontekście warto przytoczyć uwagi Stephena Turnera na temat dookreślenia miejsca socjologii w odniesieniu do demokracji liberalnej ${ }^{14}$. Typ socjologicznej działalności naukowej, który Michael Burawoy uprawomocnia jako organiczną socjologię życia publicznego, jest działalnością zaangażowaną (advocacy scholarschip). W zamierzeniu dąży do rozumienia i wyrażania punktu widzenia pewnej grupy w społeczeństwie - w sposób zrozumiały i pouczający dla członków tej grupy. Jak zauważa Turner, takie użycie wsparcia nie jest zgodne z liberalizmem: jego partnerem nie jest społeczeństwo jako całość, ale jedynie zwolennicy określonego stanowiska. Jednak wiele państw liberalnej demokracji wspiera różne punkty widzenia, przyjmując pewne założenie neutralnego stosunku do nich. Z tego względu wparcie ze strony państwa dla przedstawicieli różnych poglądów można traktować jako środek służący do poprawienia jakości debaty publicznej ${ }^{15}$. Z punktu widzenia interesującego nas zagadnienia można zastanawiać się, w jakiej mierze tę obserwację da się

${ }^{11}$ M. Burawoy, 2004 American Sociological Association Presidential Address "For Public Sociology”, „The British Journal of Sociology” 56(2), 2005, s. 259-94; idem, Krytyczny zwrot ku socjologii obywatelskiej, „StanRzeczy” 2011, 1(1), s. 193-208; S.P. Turner, Public Sociology and Democratic Theory, „Sociology” 41(5), 2007, s. 785-798.

12 J. Rawls, Liberalizm polityczny, tłum. A. Romaniuk, PWN, Warszawa 1998, s. 194.

13 C. Laborde, Critical Republicanism: The Hijab Controversy and Political Philosophy, OUP, Oxford 2008; idem, Français, encore un effort pour être républicains!, Éditions du Seuil, Paris 2010, idem, Liberalism's Religion, HUP, Cambridge, MA, 2017, oraz recenzja tej książki J.-F. Spitz, , "Une théorie libérale de la religion», „La Vie des idées”, 11 octobre 2017; J.L. Cohen, C. Laborde (eds.), Religion, Secularism, \& Constitutional Democracy, CUP, New York 2015; C. Laborde, A. Bardon (eds.), Religion in Liberal Political Philosophy, OUP, Oxford 2017.

14 S.P. Turner, Public..., w której odnosi się do propozycji amerykańskiego socjologa Burawoya, 2004 American... Kwestię tę analizuję szerzej w: Rola nauki w demokracji liberalnej. Subiektywny przeglad zagadnień, „Zagadnienia Naukoznawstwa”2016, nr 1(207), s. 63-82.

15 S.P. Turner, op. cit., s. 793. 
uogólnić w odniesieniu do nauki w ogóle, zwłaszcza w aspekcie znaczeniowym tego terminu rozumianego jako procesu nauczania i efektu kształcenia ${ }^{16}$.

W kontekście zróżnicowanych opcji aksjologicznych można zadać pytanie o to, czy i w jakim stopniu uczelnia może się nie tylko przyczynić do wspierania pewnej formy ekspertów, którymi okazują się nie tylko socjologowie obywatelscy (życia publicznego), lecz także ich potencjalni odbiorcy, których można określić mianem światłych obywateli, uwzględniając wyróżniajacy ich modus odnoszenia się do otaczającego ich świata (pod względem formy dyskursywnej) ${ }^{17}$. Zatem można zadać pytanie, czy respektujacc pluralizm aksjologiczny i nie narzucajacc nikomu „rozległej doktryny moralnej”, uczelnia może ze względu na typ dyskursu, którym operuje jednostka, promować (w duchu socjologii obywatelskiej) ten najbardziej optymalny dla funkcjonowania całości społeczeństwa.

Wyróżnione powyżej kwestie sa jedynie wybranymi problemami, które w tym kontekście można wyróżnić i bynajmniej nie wyczerpują całości interesującego nas zagadnienia. Niemniej w świetle tak zasygnalizowanych zagadnień, stawiam tezę, która wstępnie wyraziłem już w tzw. banalnej interpretacji problemu analizowanego w tekście, że niezależnie od dających się wysunąć zastrzeżeń można przypisać uczelni (obowiązek) odpowiedzialność za kształtowanie postaw obywatelskich studentów, dlatego że:

a) obok przekazywanej wiedzy specjalistycznej (treść) uczelnia uczy pewnego sposobu myślenia i daje pewien kapitał poznawczy (epistemiczny), który pozwala na (krytyczne) rozróżnianie między rzeczową i dobrze uargumentowaną wiedzą (zbiorem informacji) i informacją pozorna;

b) absolwent uczelni staje się potencjalnym interesariuszem w wielu obszarach (sferach), zatem jakość jego wyborów ma jak najbardziej znaczenie nie tylko dla niego, ale i dla całej społeczności;

${ }^{16}$ S. Kamiński, Nauka i Metoda. Pojęcie nauki i klasyfikacji nauk, IN KUL, Lublin 1992, s. $14-15$ i $17-18$.

${ }^{17} \mathrm{~W}$ tym kontekście nawiązuję do moich wcześniejszych tekstów, w których podejmowałem pytanie, czy wspólnota polityczna może preferować określony model obywatelstwa przy jednoczesnym założeniu wolności negatywnej (jako braku ingerencji) oraz politeizmu aksjologicznego (wielości faktycznie wyznawanych systemów wartości), które miałby charakteryzować współczesne społeczeństwa. Starałem się wykazać, że biorąc pod uwagę społeczne zróżnicowanie wiedzy (za Alfredem Schützem), pewien typ (model światłego) obywatela mógłby być preferowany przez wspólnotę polityczną ze względu na sposób odnoszenia się przezeń do rzeczywistości kulturowej, społecznej czy politycznej. Mam tu na myśli esej Alfreda Schütza, w którym wyróżnia trzy typy poznawczego stosunku do świata, specjalisty, człowieka z ulicy i światłego obywatela, której to kategorii przypisuje specjalne znaczenie w systemie demokratycznym - zob. A. Schütz, The Well-Informed Citizen: An Essay on the Social Distribution of Knowledge, w: idem, Collected Papers, vol. 2, Martinius Nijhoff, The Hague 1964, s. 120-134 (wyd. pol.: Światty obywatel: Esej o spotecznym zróżnicowaniu wiedzy, tłum. D. Lachowska, „Literatura na Świecie” 1985, 2(163), s. 269284). Zob. R.P. Wierzchosławski, Czy wspólnota państwowa jest odpowiedzialna za ksztattowanie modelu obywatela? Argument $z$ dystrybucji wiedzy, w: J. Miklaszewska (red.), Rozum a porzqdek społeczny, Księgarnia Akademicka, Kraków 2002, s. 263-288; idem, The well-informed citizen and axiological polytheism of liberal society: can the political community prefer a model of citizenship, w: P.W. Juchacz, R. Kozlowski (red.), Freiheit und Verantwortung: Moral, Recht und Politik, Peter Lang Verlag, Hamburg Reihe Dia-Logos, 2002, nr 1, s. 63-79. 
c) w spluralizowanym społeczeństwie istotne jest znalezienie obywatelskiego metajęzyka (problem sfery publicznej w republice), który umożliwi przedstawicielom różnych sfer prywatnych znalezienie platformy porozumienia. W tym sensie można argumentować, że od osoby z wykształceniem wyższym można oczekiwać, iż racjonalny modus operandi będzie stosowała nie tylko w przypadku działań zawodowych, lecz także angażując się jako światły obywatel, a co najmniej jako krytyczny odbiorca ofert przedstawianych in foro publico.

Przez postawy proobywatelskie (obywatelskość) w kontekście odpowiedzialności uczelni wyższej w stosunku do studentów rozumiem takie kształtowanie pewnego krytycznego stosunku do świata, w którym podmiot w wyniku procesu kształcenia domaga się od interlokutorów pewnych racji (dostatecznych) jako wymogu uznania oferowanych mu poglądów za spełniające kryterium racjonalności. A na dalszym etapie pozwala na uznanie tych poglądów za przesłanki praktyczne do podjęcia działań, które zorientowane będą nie tylko na cele jednostkowe, lecz także na cele zbiorowe. Idę tu za intuicją Arystotelesa dotycząca społecznej (wspólnotowej) natury człowieka, że sam może żyć jedynie bóg lub zwierzę, a wspólnota jest konieczna do osiagnięcia pewnych dóbr ważnych dla wszystkich obywateli ${ }^{18}$.

Nie przesądzam w tym kontekście charakteru relacji wiążących obywateli takiej wspólnoty (komunitarianizm, liberalizm, republikanizm, solidaryzm itp.). Niemniej niezależnie od wchodzących w grę rozwiązań uważam, że podstawa proponowanej tu postawy obywatelskiej jest właśnie krytyczny stosunek do świata $\mathrm{w}$ sensie epistemicznym, a dopiero $\mathrm{w}$ sensie pochodnym gotowość do takiego czy innego zaangażowania w sprawie dobra wspólnego. Takie rozumienie jest być może obciążone pewnym intelektualizmem, w tym sensie, że zakładam pierwotność rozumienia świata (w tym i społecznego) w stosunku do skutecznego działaniu na rzecz wspólnoty jako całości, jak i poszczególnych jej członków, uwzględniając tu różne stopnie kręgów bliskości/dystansu społecznego. Jednocześnie rozumienie, o które chodzi, może dokonywać się na różnych poziomach wiedzy, w tym kontekście nie ograniczam się bynajmniej do wiedzy naukowej jako jedynej czy też z góry uprzywilejowanej.

\section{ODPOWIEDZIALNOŚĆ EPISTEMICZNA OBYWATELA A ZJAWISKO POSTPRAWDY}

Jako przykład sytuacji, która komplikuje powyższe zadanie, można wskazać tę opisaną we wrześniowym numerze prestiżowego brytyjskiego tygodnika „The Economist” z 2016 r., który został poświęcony zjawisku postprawdy, jako nowej postaci kłamstwa w polityce i rozpowszechnianiu informacji w przestrzeni publicznej. Z interesujacego nas tutaj punktu widzenia można zauważyć, że zasygnalizowany przez dziennikarzy problem wskazuje na

${ }^{18}$ Arystoteles, Polityka, ks. I, 9-12 [1253a]. 
ogólne ramy tematyczne inspirujące powstanie tego tekstu. Wspomniany artkuł można potraktować jako zasygnalizowanie nowego fenomenu, jaki pojawia się w komunikowaniu społecznym. A w konsekwencji próbę zrozumienia mechanizmów skutecznego przekazu informacji pozornych (fake news), które byłyby bez zakwestionowania przyjmowane przez odbiorców. Najbardziej wyraźnym przykładem tego zjawiska miała być, zdaniem dziennikarzy, kampania wyborcza ówczesnego kandydata, a obecnego prezydenta USA. Przekazywanie wiadomości pozornych i półprawd miało nie tyle odwracać uwage od niewygodnych faktów czy też dążyć do ich ukrycia, ile kreować rzeczywistość ${ }^{19}$.

Paradoksalnie można postawić hipotezę, że fenomen postprawdy pojawia się w społeczeństwach, które socjologowie określają mianem społeczeństw opartych na wiedzy. Społeczeństw, w których cyrkulacja wiedzy jest powszechna, w których wiedza na różnych poziomach specjalizacji, będącej wynikiem społecznego zróżnicowania wiedzy, jest dostępna dla przedstawicieli wszystkich grup społecznych. Jednocześnie są to społeczeństwa wysoko rozwinięte pod względem technologicznym (społeczeństwa postprzemysłowe) oraz egalitarne pod względem ideałów społecznych i organizacji systemów politycznych (ideał demokracji). Nie oznacza to, że wcześniejsze zróżnicowania klasowe, majątkowe czy też edukacyjne zupełnie zaniknęły, wręcz przeciwnie, jak sugerują niektórzy, dochodzi do jeszcze większego zróżnicowania w obrębie tych społeczeństw ${ }^{20}$.

\section{PRZEMIANY W OBSZARZE WZORCÓW UPRAWIANIA NAUKI: OD «REPUBLIKI UCZONYCH» DO «DOBRZE UPORZĄDKOWANEJ NAUKI»}

Przywołanie zjawiska postprawdy, które można potraktować w kategoriach niezamierzonej konsekwencji komunikowania się $\mathrm{w}$ społeczeństwach opartych na wiedzy jest, moim zdaniem, ważne w kontekście przemian, jakie zaszły w obrębie społecznego rozumienia nauki i technologii, rozumianej zarówno jako czynność, jak i jako wytwór, a nade wszystko jako instytucja. Zmiana ta jest istotna $\mathrm{w}$ kontekście rozumienia roli i zadań uniwersytetu. Upraszczając, można powiedzieć, że dotychczasowy model funkcjonowania instytucjonalnie rozumianej nauki w społeczeństwie charakteryzował się następujacymi wyznacznikami:

19 „The Economist”, Post-truth politics: art of the lie (Sep. 10, 2016). W polskiej publicystyce można przywołać numer specjalny „Polityki” zatytułowany: Wielkie Post, „Niezbędnik Inteligenta” 2017, nr 1. Szersze omówienie tej hipotezy w: R. Wierzchosławski, Naukowcy w roli ekspertów. O pewnych problemach (re-)prezentacji prawdy w polityce, „Zagadnienia Naukoznawstwa” 2017, 2(212), s. 207-231.

${ }^{20}$ N. Stehr, Knowledge Societies, Sage, London 1994; idem, The Fragility of Modern Societies: Knowledge and Risk in the Information Age, London, Sage Publications, London-ThousandOaks-New Delhi 2001; idem, Die Freiheit ist eine Tochter des Wissens, Springer Fachmedien, Wiesbaden 2015; idem, Information, Power, and Democracy. Liberty Is a Daughter of Knowledge, CUP, Cambridge 2016. 
1) Za Maxem Weberem neutralnością aksjologiczna, czyli wolnością od wartościowań (przy jednoczesnym odniesieniu do wartości w kwestii wyboru aspektu, z punktu widzenia którego badany jest dany przedmiot materialny). Biorąc pod uwagę burzliwe czasy końca I wojny światowej, kiedy to postulat ów został sformułowany w słynnym wykładzie Wissenschaft als Beruf, Weber miał na myśli przede wszystkim to, aby katedry uniwersyteckie nie stawały się ambonami, z których wygłaszane sa kazania ideologiczne, czy też trybunami partyjnej agitacji. Można powiedzieć, że postulat nauki wolnej od wartościowań chroni uczonych i studentów w sytuacji ewentualnych zagrożeń. By przypomnieć minione czasy, nierzadko wybór formalnych czy metodologiczno-teoretycznych specjalności naukowych był podyktowany ucieczką przed grożącym zaangażowaniem w sferę ideologiczno-polityczną ${ }^{21}$.

2) Autonomia funkcjonowania nauki, której locus naturalis, jak zauważył inny klasyk gatunku Robert K. Merton, jest ład demokratyczny, to w układzie wolności myśli i działania nauka może rozwijać się najlepiej. W szkicach z socjologii nauki Merton kontrastuje naukę w demokracji z totalitaryzmem hitlerowskim (lata 30.), a w późniejszych wydaniach również z totalitaryzmem sowieckiego komunizmu (zwłaszcza lata 50. i 60.) ${ }^{22}$. Jeśli idzie o wewnętrzna organizację nauki, to w tym ujęciu mamy do czynienia z republiką uczonych, którzy sami określają cele oraz zasady podziału środków na ich realizację. Społeczeństwo i politycy nie wtrącają się (zasadniczo) do samorządnej struktury świata uczonych, który rządzi się swoim prawami. Przykładem takich wewnętrznych regulacji może być chociażby sławetny ethos uczonych podany przez Mertona, który charakteryzuje się następującymi wyznacznikami:

a) uniwersalizm: gwarantujący obiektywność kryteriów akceptacji wytworów oferowanych przez środowisko uczonych;

b) komunizm: zgodnie, z którym uzyskane rezultaty są własnościa wspólnoty uczonych i moga być wykorzystywane przez wszystkich (problem dostępu);

c) bezinteresowność: poznanie dla niego samego, czyli znaczenie badań teoretycznych i nieuwarunkowanych kryterium stosowalności wyników oraz szybkich zysków z poniesionych nakładów (wymóg mocno zagrożony w świecie komercjalizacji nauki, przesunięcia się badań do prywatnych koncernów, np. sektor biotechnologiczny oraz problem ekonomizacji wiedzy jako wytworu i jej zastosowań technologicznych);

d) zorganizowany sceptycyzm - w stosunku do innych typów wiedzy ludzkiej, zwłaszcza w kontekście poznania potocznego oraz form ideolo-

${ }^{21}$ M. Weber, Wissenschaft als Beruf, w: Gesammelte Aufsätze zur Wissenschaftslehre, J. Winckelmann (Hrsg.), J.C.B. Mohr (Paul Siebeck) Verlag, Tübingen 1922, s. 582-613; M. Weber, Polityka..., s. 55-110.

${ }^{22}$ M. Polanyi, The republic of science: its political and economic theory, „Minerva” 1(1), 1962, s. 54-73; R.K. Merton, The Sociology of Science: Theoretical and Empirical Investigations, UCHI Press, Chicago 1973; idem, Teoria socjologiczna i struktura społeczna, PWN, Warszawa 1982 , s. 566-578. 
gicznych (autorytarnych), dziś może mieć znaczenie w kontekście rozmywania się rzetelnego poznania $\mathrm{w}$ inflacyjnym zalewie pozornych informacji ${ }^{23}$.

Model nauki przedstawiony przez Mertona przynależy z różnych względów do przeszłości. Nie oznacza to rzecz jasna, że wszystkie z postulowanych przezeń wyznaczników dobrej nauki (ethos nauki) się zdezaktualizowały, ale niewątpliwie w porównaniu z czasami postulowanej przezeń „republiki uczonych" radykalnie zmieniło się zewnętrzne otoczenie nauki. Badania naukowe nie sa prowadzone jedynie w instytutach badawczych uniwersytetów czy też wyspecjalizowanych jednostkach akademii nauk, które mają zapewnione finansowanie ze strony budżetu państwa (model europejski) bądź też prywatnych donatorów sponsorujących dany uniwersytet (model amerykański). W obu tradycjach pojawia się coraz częściej tzw. partnerstwo publiczno-prywatne, które ma zapewnić stosowne fundusze. Zatem wzrasta waga czynnika ekonomicznego, jako warunkującego uzyskanie „zielonego światła” dla prowadzenia badań naukowych, z tego względu, że wyłożone fundusze powinny się zwrócić (kwestia niepowodzeń) z nawiązka. Tym samym to nie badacz (czy też ich grupa) ma zasadniczy wpływ na temat badań, ale sponsorzy, oni też decyduja o preferencjach dla całych dyscyplin czy też (interdyscyplinarnych) obszarów badawczych ${ }^{24}$. Sytuacja ta znajduje swoje odbicie w filozoficznej lub też socjologicznej refleksji nad nauka, w której coraz częściej pojawiają się takie kategorie, jak prawdy (w sensie praktycznym czy aplikacyjnym) istotnie doniosłe (significant truth) ${ }^{25}$ bądź określanie wiedzy w kategoriach możliwości i zdolności do działania (capacity to act) ${ }^{26}$. W tym ostatnim użyciu można usłyszeć stare adagio obecne już u Bacona, a potem w pragmatycznym podejściu do wiedzy, która rozumiana jest jako potęgi klucz (knowledge is power) ${ }^{27}$.

${ }^{23}$ Ibidem, 578-589; Warto przywołać w tym miejscu prace Janusza Goćkowskiego, który bronił ethosowego rozumienia nauki w mniej lub bardziej opresyjnych okresach minionych czasów: Autorytety świata uczonych, PIW, Warszawa 1984; idem, Ethos nauki i role uczonych, Secesja, Kraków 1996, jak również wydaną jeszcze na emigracji książkę niezapomnianego Jakuba Karpińskiego, która może być dobrą ilustracją realizacji postulatu „zorganizowanego sceptycyzmu”: Nie być w myśleniu postusznym: Ossowscy, socjologia, filozofia, Polonia Book Found Ltd., Londyn 1989. Z punktu widzenia ogólnej metodologii nauk temat odpowiedzialności podejmuje Andrzej Bronk, Odpowiedzialność uczonych: uwagi metodologa, Publikacja FNP zawierająca materiały pokonferencyjne FNP 2010, s. 85-94 [w druku].

${ }^{24}$ Dobry przegląd dyskusji na temat zewnętrznego otoczenia, w ramach którego funkcjonuje współczesna nauka i jej technologiczne zastosowania, można znaleźć w pracy J. Van Bouwel (ed.), The Social Sciences and Democracy, Palgrave Macmilan, London 2009 czy też S. Jasnoff, Designs on Nature. Science and Democracy in Europe and in the United States, PUP, Princeton 2005. W literaturze polskiej można przywołać opublikowaną niedawno pracę toruńskiego filozofa polityki J. Grygieńcia, Demokracja na rozdrożu. Deliberacja czy partycypacja polityczna?, Universitas, Kraków 2017, w której analizuje aspekt obywatelskiego zaangażowania w sprawy publiczne i różne formy polityzacji ekspertów. Do kwestii tej powrócę w dalszej części artykułu.

25 P. Kitcher, Science, Truth, and Democracy, OUP, Oxford 2001; idem, Science in a Democratic Society, Prometheus Books, Amherst, NY, 2011.

${ }^{26}$ N. Stehr, Die Freiheit ist eine Tochter des Wissens, Springer Fachmedien, Wiesbaden 2015; idem, Information, Power, and Democracy. Liberty Is a Daughter of Knowledge, CUP, Cambridge 2016.

27 M. Adolf, N. Stehr, Knowledge. Is Knowledge Power?, Routledge, London 2017. 
Zasygnalizowane powyżej zmiany nie tylko pociagają za sobą określone konsekwencje w sposobie uprawiania nauki i jej technologicznych zastosowań, lecz także wiążą się ze wzrastająca świadomością rozmaitych zagrożeń, które niosą z sobą dla użytkowników i odbiorców tak rozumianej wiedzy i technologii. Nie bez przyczyny bowiem pojęcie "społeczeństwo ryzyka» pojawiło się w konsekwencji katastrofy w Czarnobylu. Fakt ów uświadomił globalny wymiar ryzyka, jakie niosą z sobą zaniedbania bądź niedajace się przewidzieć lub niezamierzone skutki uboczne postępu naukowego i technologicznego ${ }^{28}$. W tym kontekście można zaobserwować wzrastające zjawisko nieufności w stosunku do samych zdobyczy technologicznych. Pojawia się społeczna obawa, że ich funkcjonowanie może się w pewnym momencie wymknać spod kontroli i doprowadzić do katastrofy na skutek braku możliwości przewidzenia niezamierzonych skutków ubocznych, które pojawiają się w stosowaniu owych technologii (np. wzrost plonów dzięki zastosowaniu chemicznych środków ochrony rośli, który prowadzi do zanieczyszczenia wód gruntowych i zmian w dotychczasowych ekosystemach). Przykłady można mnożyć29.

Inną formą reakcji moga być coraz bardziej rosnące w siłę ruchy oddolnego sprzeciwu w stosunku do odgórnego stosowania (a zarazem narzucania) paradygmatu dominacji technologicznej, jeśli można posłużyć się tym terminem, np. w medycynie ruchy antyszczepionkowe, w środowiskach konsumentów sprzeciw w stosunku do rolnictwa stosujacego GMO itp. Tego typu ruchy moga być przejawami sprzeciwu, który rodzi się nie tylko dlatego, że ich członkowie dostrzegają te czy inne zagrożenia, lecz także w swych konsekwencjach moga prowadzić do wzrostu postaw irracjonalnych, w których odrzuca się wszystko co tylko kojarzy się ze scjentystyczno-technologicznie rozumianą nauką ${ }^{30}$.

W kontekście wskazanych powyżej kwestii wzrasta rola krytycznej świadomości obywateli, którzy jako interesariusze reprezentujący różne ciała społeczne, czy też jako lokalni mieszkańcy, którzy stają w obliczu takich lub innych decyzji administracyjnych wydawanych w odniesieniu do spraw będących w ich bezpośrednim zainteresowaniu (np. lokalny krajobraz zagrożony centralną inwestycją czy skażenie okolicznych rzek wskutek nadmiernego stosowania nawozów w ramach intensywnego rolnictwa), czy też jako obywatele majaccy na celu dobro wspólne (np. zasoby naturalne, które należy zachować dla przyszłych pokoleń, by przywołać kontrowersje wokół wycinki drzew w Puszczy Białowieskiej) muszą się ustosunkować do zagrożeń tego typu i podjać stosowne działania w imię odpowiedzialności za dobro własne, również w wymiarze transgeneracyjnym.

Tego typu działania mogą być podjęte właśnie ze względu na kapitał społeczny wyniesiony w procesie kształcenia, który uruchamia pewną wrażliwość obywatelską w sytuacji powstajacych zagrożeń. Kwestie te dobrze diagnozuje konserwatywny filozof brytyjski Roger Scruton w swojej pracy poświęco-

${ }^{28}$ U. Beck, Społeczeństwo...; N. Stehr, The Fragility of Modern Societies: Knowledge and Risk in the Information Age, Sage Publications, London 2001.

${ }^{29}$ F. Fischer, Citizens..., passim.

30 Idem, Democracy..., passim. 
nej zagadnieniom ekologii: Zielona filozofia $a^{31}$. Podkreśla on, jak wiele działań obywatelskich było podejmowanych ze względu na świadomość określonych wartości kulturowych i przyrodniczych, która powstawała w wyniku prospołecznej czy też obywatelskiej edukacji (na różnych jej poziomach). Dla samego Scrutona przykładem takiego zaangażowania w ochronę wartości przyrodniczych regionu (autor określa takie nastawienie mianem oikofilia) był jego ojciec. Jako lokalny nauczyciel propagował on wśród swoich uczniów postawy i wzorce aktywności obywatelskiej od najmłodszych lat, co w dorosłym życiu przyniosło pożądane rezultaty. Przykład ten można traktować jako wsparcie bronionej w artykule hipotezy.

Mówi się zatem - jak głosi to jeden ze współczesnych filozofów nauki, który bada funkcjonowanie nauki w jej zewnętrznym (społeczno-politycznym) otoczeniu - że nauka nie poszukuje prawdy po prostu, ale prawd istotnych (significant truth), gdyż świat jest zaludniony wieloma zdaniami prawdziwymi. Prawda jest istotna dla danej osoby, gdy wiedza ta zwiększa szanse na osiagnięcie praktycznych celów ${ }^{32}$. Tym samym mamy do czynienia z pewną pragmatyzacją nauki, która ma na celu wypracowanie nowego konsensu między poszukiwaniem wartości poznawczych a wartościami społecznymi istotnymi dla społeczeństw demokratycznych, który to konsens określałby ramy dobrze uporządkowanej nauki (well-ordered science). Przy takim rozumieniu nauki, niezależnie od tego, jak bardzo abstrakcyjnych i oderwanych od codzienności obiektów się poszukuje, musi ona respektować pewne wymagania stawiane w kontekście ram społecznych, w obrębie których funkcjonuje.

\section{EKSPERCI, REPREZENTACJA, OBYWATELE A SPOŁECZEŃSTWA OPARTE NA WIEDZY}

Wspomniałem przy okazji fenomenu postprawdy, że może być on niezamierzonym skutkiem ubocznym społeczeństwa opartego na wiedzy. Termin ten rozpowszechniony m.in. przez niemieckiego socjologa Nico Stehra i jego współpracowników może być traktowany jako pojęcie zwierające najróżniejsze aspekty, które charakteryzują (a) zachodzące przemiany w obrębie różnych typów wiedzy we współczesnym świecie, (b) przemiany społeczno-kulturowe, które zachodza pod wpływem wiedzy i technologii obecnych w ich ramach. Można powiedzieć, że społecznie uprawomocniona wiedza charakteryzuje funkcjonowanie współczesnych społeczeństw w stopniu zdecydowanie większym niż w przeszłości. Nauka (rozumiana w sensie jej owoców) i technologia są coraz bardziej istotne w naszym życiu codziennym i przenikają się nawzajem. Wiedza nie tylko odkrywa nowe obszary świata, nie tylko pozwala nam

${ }^{31}$ R. Scruton, Zielona filozofia: Jak poważnie myśleć o naszej planecie, tłum. J. Grzegorczyk, R.P. Wierzchosławski, Zysk i S-ka, Poznań 2017.

${ }^{32}$ P. Kitcher, Science..., s. 73. 
działać w świecie na różnych poziomach, lecz także w pewnych jego obszarach tworzy nowy świat (np. klonowanie) ${ }^{33}$.

Wskazując na problemy, z którymi mamy do czynienia w przypadku kwestii odpowiedzialności w kontekście współczesnego funkcjonowania nauki i technologii w przestrzeni społecznej, zwróciłem uwagę na asymetrię poznawcza, która pojawia się w przypadku odwołania się do wiedzy i korzystania z usług ekspertów. Jakkolwiek w literaturze przedmiotu dyskutuje się, czy zainteresowani laicy sa w stanie kontrolować od strony poznawczej argumentację ekspertów, a co najmniej podążać za prowadzonym przez nich dyskursem, sytuacja taka miałaby znaczenie dla obywatelskiego zaangażowania w dialogu z ekspertami na temat problemów, do rozwiązania których zostali wynajęci, jak również, kwestii proponowanych przez nich rozwiązań tych problemów ${ }^{34}$. Jednakże zasadniczo przyjmuje się fakt zachodzenia takiej asymetrii, chociaż uznaje się, że w zależności od dziedziny, w obrębie której świadczone są usługi eksperckie, zróżnicowanie to będzie przybierało różny formy (stopniowalność). Nie zawsze opinie ekspertów będą cieszyły się wzajemnym konsensem oraz wiarygodnym uzasadnieniem receptur przez nich przekazywanych. Inna jest wiarygodność fizyka, inna klimatologia, a jeszcze inna ekonomisty. Można powiedzieć, że w powyższym wyliczeniu w każdej kolejnej dyscyplinie maleje konsens w gronie ekspertów, a tym samym wzrastają rozbieżności co do wyrażanych przez nich opinii ${ }^{35}$. Osobna kwestia jest transparentność działania ekspertów w stosunku do opinii publicznej oraz gotowość do ponoszenia konsekwencji (odpowiedzialność eksperta) za błędne (z różnych przyczyn) ekspertyzy ${ }^{36}$.

${ }^{33}$ M. Callon, P. Lascoumes, Y. Barthe, Acting in an Uncertain World: An Essay on Technical Democracy, MIT Press, Cambridge, MA, 2009; A. Stehr, op. cit.

${ }^{34}$ H.M. Collins, R. Evans, Rethinking Expertise, UCHI Press, Chicago 2007; S.P. Turner, Liberal Democracy 3.0: Civil Society in the Age of Experts, Sage, London 2003; F. Fischer, Democracy...; J. Grigieńć, op. cit.

${ }_{35}$ Problem (potencjalnego) braku neutralności ekspertów funkcjonujących w polityce na przykładzie koncepcji neorepublikańskiej przestawiam $\mathrm{w}$ tekście The role of experts in the condominium model as republican (re)solution of social, economic, and political problems, w: C. Martini, M. Boumans (eds.), Experts and Consensus in Social Science-Critical Perspectives from Economics, Sociology, Politics and Philosophy, Ethical Economy - Studies in Economies Ethics and Philosophy, Springer Verlag, Heidelberg 2014, s. 253-274. Koncepcja republikańska ta jest w tym kontekście istotna ze względu na nacisk, jaki kładzie na związek między wolnością polityczną a statusem obywatela: libertas est civitas. Jedynie posiadając status obywatela, jednostka może cieszyć się wolnością zagwarantowaną prawnie i ograniczającą wszelkie groźby arbitralnej ingerencji ze strony innych podmiotów w zakres jej potencjalnych wyborów. Taki jest sens wolności jako braku dominacji, którą zwolennicy koncepcji republikańskiej przeciwstawiają wizji liberalnej i komunitariańskiej. Zob. P.N. Pettit, Republicanism: A Theory of Freedom and Government, OUP, Oxford 1997; idem, On the People's Terms: A Republican Theory and Model of Democracy, CUP, Cambridge, 2012. Idea ta ma również swoje szczególne zastosowanie w aspekcie edukacji publicznej, zwłaszcza w kontekście przezwyciężania partykularyzmów (sfera prywatna) oraz uczenia pewnego obywatelskiego metajęzyka, w kategoriach którego zróżnicowane grupy obywateli potrafią się wzajemnie komunikować i osiagać konsensus. Zob. zwłaszcza C. Laborde, Critical..., passim.

${ }^{36}$ Dobry przegląd i omówienie przypadków funkcjonowania ekspertów w różnych dziedzinach oraz określonych sytuacjach historycznych, zróżnicowanym stopniu transparentności itp. można znaleźć w książce S.P. Turner, The Politics of Expertise, Routledge, London 2014. Problematykę zróżnicowanych typów ekspertów w kontekście typów obywatelstwa oraz funkcjono- 
W świetle powyższych uwag wydaje się, że ważną kwestią jest świadomość kontekstualizacji i pozycjonalizacji ekspertów wypowiadajacych się w imieniu nauki na forum publicznym jako reprezentanci takich czy innych opcji ideowych, kulturowych czy politycznych. Za amerykańskim naukoznawca i politologiem Markiem B. Brownem możemy zatem mówić o polityzacji nauki $^{37}$. Brown uważa, że odwołanie się do wiedzy w kontekście podejmowania decyzji politycznych wiąże się z problemem polityzacji nauki i nie należy tego faktu ukrywać, ale znaleźć satysfakcjonujące rozwiązanie. Politycy, szukając uzasadnienia podejmowanych decyzji, przywołuja tych czy innych ekspertów, a ich wybór jest zabiegiem politycznym, gdyż eksperci mają przede wszystkim potwierdzić przyjmowane przez polityków stanowisko w danej kwestii. Kryterium doboru ekspertów jest właściwa reprezentacja stanowiska właściwego dla danej opcji politycznej, która w tym kontekście jest rozumiana szeroko: światopoglądowo, ideowo, kulturowo, religijnie itp.

Problem reprezentacji dotyczy tego, czy faktycznie obejmuje ona różne grupy społeczne, innym słowy, to kwestia zakresu i inkluzywności w stosunku do wszystkich opcji. Zarazem, zdaniem autora, należy skończyć z fałszywą retoryką na temat neutralności (aksjologicznej) ekspertów, którzy w swoich deklaracjach wypowiadają się jedynie w imieniu „,zystej nauki”, które to deklaracje faktycznie funkcjonuja jako zasłona dymna maskująca opcję, w imieniu której dany ekspert się wypowiada.

Jeśli uznać obserwacje Browna za zasadne, to kwestia polityzacji wiedzy i działań ekspertów stanowi ważne wyzwanie w kwestii odpowiedzialności obywatelskiej w tym sensie, że w takim układzie świadomość odbiorców (obywateli) pozapoznawczego uwikłania aksjologicznego ekspertów tym bardziej nabiera znaczenia, gdyż jest to niezbędne do właściwego odbioru opcji ideowych, które reprezentują dani eksperci. Tym samym świadomość (metodologiczna czy też epistemologiczna) obywatela dla jego krytycznego (pytanie się o racje dostateczne) odbioru oferowanych mu uzasadnień, czy to głoszonych przekonań, czy też proponowanych projektów działań, stanowi warunek sine qua non dalszego zaangażowania obywatelskiego.

\section{KONKLUZJE}

W artykule starałem się pokazać, że w kontekście przemian, jakie zachodzą w rozumieniu nauki i technologii we współczesnych społeczeństwach opartych na wiedzy, kwestia odpowiedzialności uczelni za kształtowanie postaw

wania w systemie demokratycznym omawiam w: Eksperci, laicy $i$ światli obywatele, a problem dystrybucji wiedzy spotecznie uprawomocnionej, „Roczniki Filozoficzne” 52, 2004, nr 2 (Novis vetera augere atque perficere. Księga pamiatkowa ofiarowana Księdza Profesorowi Józefowi Herbutowi), s. 365-390, oraz Politeizm aksjologiczny, władza ekspertów, a wolność obywateli. Kilka uwag o meandrach wiedzy, władzy i republice, w: A. Gawkowska, P. Gliński, A. Kościański (red.), op. cit., s. 82-109.

${ }^{37}$ M.B. Brown, Science in Democracy: Expertise, Institution and Representation, MIT Press, Cambridge, MA, 2009. Kwestie te omawiam szerzej w tekście: Naukowcy..., s. 207-231. 
obywatelskich studentów sprowadza się w pierwszym (podstawowym) wymiarze do wsparcia ich rozwoju intelektualnego (kapitał społeczny) - za Alfredem Schützem można by jednak wskazać na doniosłość typy «światłego obywatela», który w krytycznym podejściu do świata wykraczałby poza typ fachowego, zamkniętego w wieży z kości słoniowej «eksperta» oraz bezrefleksyjnego «czło-

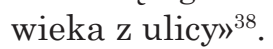

Tak intelektualistycznie rozumiana odpowiedzialność może się wiązać ze zwróceniem szczególnej uwagi przez uczelnię na uwzględnianie w programach nauczania przedmiotów (a co najmniej zagadnień) kształcących u słuchaczy umiejętności dyskursywne (teoria argumentacji, krytyczne myślenie, analiza logiczno-metodologiczna), jak również stymulujących ogólnointelektualne zainteresowania, takie jak znajomość głównych orientacji ideowych, światopoglądowych, kulturowych, wokół których toczą się debaty społeczne. Wprowadzenie przedmiotów tego typu w czasach waskiej specjalizacji zawodowej oraz skupianiu się studentów na poszukiwaniu miejsca na rynku pracy może nie być bynajmniej sprawą prostą i może spotkać się z brakiem zrozumienia zainteresowanych. Wydaje się jednak, że w kontekście inflacji informacji pozornych i szerzeniu się postprawdy działania tego typu są nie tylko pożądane, lecz że są one koniecznością.

dr Rafat Pawet Wierzchostawski

Uniwersytet Humanistycznospołeczny SWPS

Wydziat Zamiejscowy w Poznaniu

rwierzchoslawski@swps.edu.pl

\section{A UNIVERSITY'S RESPONSIBILITY FOR SHAPING STUDENTS CIVIC ATTITUDES}

Sum mary

The main problem of the paper is this: should we ascribe to the University responsibility for shaping students citizenship (civic attitudes)? It seems that such a task might be understood as a secondary or extra-cognitive educational aim of the University, which aims not only to provide knowledge in a defined domain of study required by the future occupation, but also take into account that the alumni are going to fulfil various social or political functions and they require suitable intellectual capital for it. I focus on various commitments, which condition our understanding of the knowledge and institutional frameworks in which science and education function in modern pluralistic societies. In the paper I discuss: (i) the ontological aspect of the responsibility bearer, (ii) the epistemic aspect of a special role of the man of knowledge in relation to the other members of society, (iii) axiological aspects, by which I mean the problem of axiological pluralism of our societies, (iv) the context of the post-truth phenomenon which endangers rational attitudes of citizens, (v) some pragmatic shifts in scientific practices patterns: from die Gelehrterepublik [republic of science] to well-ordered science; (vi) the role of experts as representatives of various axiological options justified by scientific knowledge in relation to decision-making in the framework of the social and political institutions of the 'knowledge society'. And in the end (vii) I formulate final conclusions in favour of my main hypothesis that the University (as a body) is responsible for students' civic attitudes in theeducational process.

${ }^{38}$ A. Schütz, The Well-Informed...; idem, Światty obywatel..., passim. 